\title{
古代地方官衙政庁域の空間構成 THE SPATIAL STRUCTURE OF LOCAL GOVERNMENT OFFICE DISTINCT IN ANCIENT TIME
}

\author{
海 野 聡*
}

Satoshi UNNO

\begin{abstract}
This study aims at revealing the original form of the government office area in local regions in the $8^{\text {th }}$ century. The research method adopted here is based on intensive examination of both historical documents and archaeological reports.

The results show mainly three conclusions. First, the local government "Kokucho" was planned by the rules according to the provincial class. Second, every "Kokucho" and "Guncho" (a lower government than "Kokucho") had "Maeniwa"(Front Yard), and it was the very important official place in the district. Third, this "Maeniwa" originated from "Oharidano Miya" in the $7^{\text {th }}$ century.

"Maeniwa is the essential space in the local government office area. The provincial governor ("Kokushi” or "Gunji”) held official ceremonies here to demonstrate the dignity of the ancient state to the local powerful families. Therefore, though the excavation results show various planning types, it was generally accepted as central place of local government office district.
\end{abstract}

Keywords : Kokucho, Guncho, Kouzukenokuni Koutai Jitsurokucho, Maeniwa(Front Yard),

Kunino Mikotomochi

国庁，郡庁，上野国交替実録帳，前庭空間，クニノミコトモチ

\section{1. はじめに}

奈良時代には、律令制度が導入され、国郡による地方支配体制が 確立した。そして大宰府、国衙、郡衙、駅家などの律令制度を支え る地方官衙が数多く設けられた。

地方官衙については、学術用語が定義されていないため、山中敏 史氏が使用する用語に倣う注 1)。即ち国衙の政庁域を国庁、郡衙の 政庁域を郡庁と呼ぶ。

政庁域の中心建物を正殿、両脇に並ぶ細長い建物を脇殿注2)、正 殿および脇殿によって囲まれた空間を前庭空間と称す (図 1 )。地方 官衙の政庁域には、正殿が中心軸に据えられ、両脇殿が中心軸に対 称に配置された。

阿部義平氏は、国庁の中にはほぼ方 形の南部分の中央に前殿が存在し、脇 殿が正殿前面より北にまで延びる点が、 平城宮太政官院曹司と類似することか ら、平城宮太政官院曹司が国庁の祖形 であった可能性を指摘している注3)。 山中敏史氏は、国庁の建物配置形式 の祖形について、大極殿、朝堂院、内

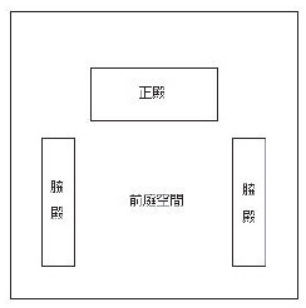

図 1 地方官衙政庁域 (作成海野)
裏内郭といった宮城中枢施設、あるいは大宰府政庁との類似性が認 められるので、国庁の構造はそうした施設を祖形として省略、変形、 合成して造り出されたものであるとする注4)

このように既往の研究では地方官衙の建物配置は、中央の権力が 地方官衙に強く影響したと考えられていたため、建物配置の祖形を 律令制の導入後の中央の宮城や官衙に求めている。

しかし一方で地方官衙の発掘遺構には中央の影響は見出し難い。 各地方官衙は、前殿、後殿の有無や脇殿の建物の数も異なる。果た して、地方官衙の建物配置は、律令制度とともに、初めて導入され た、新しい建物配置であったのだろうか。本稿では、発掘調査報告 書（文末発掘調査報告書一覧参照）と文献史料に記された前庭空間 における儀式を通して、国庁、郡庁を対象に地方官衙の建物配置の 祖形を明らかにすることを目的とする。

\section{2、国の等級による国庁の比較}

まず各国の国庁を比較することで、国庁の建物配置の特徵をみる。 国庁の建物配置は、山中敏史氏によって 3 つに類型化されている。 長舎型、大宰府政庁型、城柵政庁型の 3 つである。長舎型はもつと も一般的な形で近江(図 2-(1)、伊勢(図 2-(2))、伯者(図 2-(6)、下

\footnotetext{
$*$ 奈良文化財研究所 研究員 $\cdot$ 修士 $($ 工学 $)$
} 


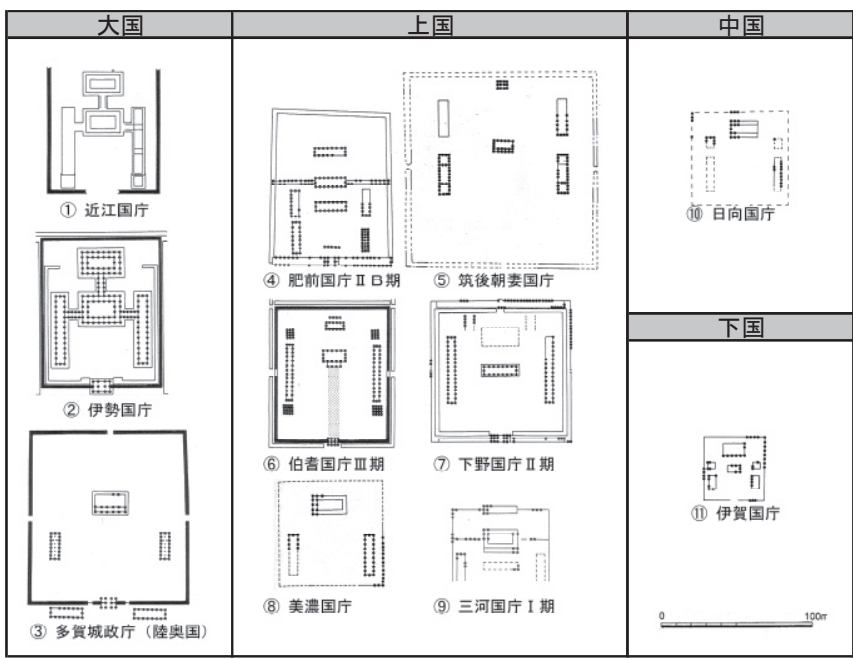

図 2 国庁の建物配置 (山中敏史氏作成注 5 )を一部改変)

野(図 2 - (7))、美濃(図 2 -8)、三河(図 2 -9))の国庁の上うに脇殿が長 大な建物でコの字型配置をとる。大峷府政庁型は肥前(図 2 -(4)、筑 後朝妻(図 2 -(5))、伊賀(図 2 -(11) の国庁のように脇殿を左右に 2 棟ず つ配置したコの字型配置である。城柵政庁型は陸奥(図 2 -(3)、出羽 国庁（城輪柵遺跡）のように正殿と桁行の短い両脇殿を品字に配置 する。

このように山中敏史氏は国庁建設後の検出遺構を分類するが、計 画段階における考察を欠く。そのため計画段階における、国の等級 と建物配置の関係について検討する。

国の等級は時代によって変化しており、さらに国庁の建設された 時期も不明であり、国ごとに異なる。よって本稿では、『延喜式』の 民部式によって記された国々の等級区分をもとに分類する注 6$)$ 。な お現在までに国庁や正殿の明らかとなっている国庁のうち、出羽国 は対蝦夷政策の進行状況に合わせて、城輪椢、秋田城の 2 个所に国 庁が移転しており、多賀城以上に城柵としての性格が強いため除外 して考察する。それ以外の国庁配置図を国の等級によって分類した ものが図 2 である。

まずは大国の特徵を検討する。大国の国庁の判明する遺跡は近江、 伊勢、陸奥 (多賀城) の 3 国である(図 2)。

伊勢は伊勢神宮を擁した神郡があり、神祇政策上、重要な地であ る。また近江は大津京が置かれた特別な地である。そのため大国の 中でも特別な扱いであった可能性がある。よってこの 2 国をもつて 大国の国庁を一般化することははばかられるが、2 国の国庁は規模 もほぼ等しく、基壇・軒廊を用いて、正殿の背部に後殿を配置して おり、類似している。

この 2 国の大国の国庁を上国（下野、三河、筑後朝妻、伯者、美 濃、肥前）の国庁と比較すると、国庁の広さはほぼ同じであるが、 上国の国庁には大国に見られる脇殿と正殿をつなぐ軒廊が存在し ない。この正殿から両脇殿や後殿へとつながる軒廊を備える点は、 大国のみに見られる特徵である。この軒廊に注目すると、軒廊は正 殿から他の建物に連結している。このことから業務の中心は正殿で 行われ、さらに後殿や脇殿といったほかの建物に軒廊を通って移動 する必要があったと推定できる。

ではこの軒廊は何のために造られたのであろうか。

まず考えられるのは、機能的要求によるものである。確かに大国
表 1 国庁の政庁域と前庭空間

\begin{tabular}{|c|c|c|c|c|c|c|c|c|c|}
\hline \multirow[b]{2}{*}{ 等級 } & \multirow[b]{2}{*}{ 国名 } & \multicolumn{3}{|c|}{ 政庁域 } & \multicolumn{3}{|c|}{ 前庭 } & \multirow[b]{2}{*}{$\begin{array}{l}\text { 䯚殿 } \\
\text { (楝) }\end{array}$} & \multirow[b]{2}{*}{ 備考 } \\
\hline & & $\begin{array}{l}\text { 東西 } \\
(\mathrm{m})\end{array}$ & \begin{tabular}{|c|} 
南北 \\
$(\mathrm{m})$ \\
\end{tabular} & $\begin{array}{l}\text { 面積 } \\
\left(\mathrm{m}^{2}\right)\end{array}$ & $\begin{array}{l}\text { 東西 } \\
(\mathrm{m})\end{array}$ & $\begin{array}{l}\text { 南北 } \\
(\mathrm{m})\end{array}$ & $\begin{array}{l}\text { 面積 } \\
\left(\mathrm{m}^{2}\right)\end{array}$ & & \\
\hline & 大宰府 & 114 & 200 & 22800 & 57 & 97 & 5529 & 4 & 政庁域が回廊によって分かれる。 \\
\hline \multirow{3}{*}{ 大国 } & 陸奥(多賀城) & 103 & 117 & 12051 & 66 & 57 & 3762 & 2 & \\
\hline & 近江 & 74 & 86 & 6364 & 37 & 37 & 1369 & 2 & 政庁域南北確定せず。 \\
\hline & 伊勢 & 83 & 100 & 8300 & 43 & 34 & 1462 & 2 & \\
\hline \multirow{8}{*}{ 上国 } & 美濃 & 71 & 71 & 5041 & 43 & 49 & 2107 & 2 & 政庁域は確定せず。 \\
\hline & 三河 & 64 & & & 46 & & & 2 & 政庁域が回廊によって分かれる。 \\
\hline & 下野 & 94 & 94 & 8836 & 60 & 40 & 2400 & 2 & 後殿がある可能性あり。 \\
\hline & 出羽(秋田城) & 89 & 74 & 6586 & & 40 & & 2 & \\
\hline & 出羽(城輪柵) & 126 & 126 & 15876 & 67 & 66 & 4422 & 2 & 政庁域南北は不明 \\
\hline & 伯耆 & 83 & 97 & 8051 & 51 & 49 & 2499 & 2 & \\
\hline & 筑後朝妻 & 126 & 131 & 16506 & 71 & 74 & 5254 & 4 & 政庁域南北確定せず。 \\
\hline & 肥前 & 83 & 103 & 8549 & 40 & 31 & 1240 & 4 & 政庁域が回廊によって分かれる。 \\
\hline 中国 & 旦向 & 63 & 63 & 3969 & 40 & 46 & 1840 & 4? & 政庁域は確定せず。 \\
\hline 下国 & 伊賀 & 40 & 43 & 1720 & 20 & 20 & 400 & 2 & \\
\hline
\end{tabular}

では業務を行ううえで、脇殿と正殿の往来を頻繁に行う必要があつ たために、正殿と脇殿を軒廊でつないだ可能性も考えられる。しか し大国と上国で人員の差が少ないことから業務量に大きな差があ ったとは考えにくく、この可能性は低い注 7)。この業務量の差が少 ない点は、業務を行う国庁の広さが大国と上国でほぼ等しいことに も表れている。

寧ろ、機能面以外の要求によって造られたのではないであろうか。 つまり軒廊は大国と上国の実用面での差によって造られたのでは なく、大国のみに許された形式であったと考えられる。この点は、 大国以外の上国、中国、下国には軒廊が見られず、大国にのみに見 られることから確認できる。このように大国と上国の差は国庁の広 さによって示したのではなく、軒廊で建物をつなぐ形式によって示 したといえる。

同じく大国である陸奥には伊勢や近江に見られる軒廊が存在しな い。そして他の国庁を比べても、前庭空間が非常に大きい(表 1 )。 これには多賀城の性格と関係している。多賀城は鎮守府も兼ねてお り、軍事拠点としての性格が強く、兵士の集結という城柵としての 機能を求められたため、前庭空間を広くしたと推定できる。この点 は、表 1 のように出羽や筑後の国庁も、多賀城と同様に前庭空間が 大きいことから確認できる。出羽は軍事的な機能を有し、蝦夷との 抗争の激しかった東北の城柵であり、筑後は防人が置かれた地であ り、両国ともに、軍事的に重要な拠点であった。このように陸奥・ 出羽・筑後といった軍事的に重要な国には、広い前庭空間が設けら れたのである。

これまで述べてきたように大国においては、正殿から後殿や脇殿 へつながる軒廊を用いる形式が成立していた。そして軍事的に重要 な国の国庁の前庭空間は例外的に広く、兵士の集結場所として利用 されていたと考えられる。

次に上国、中国、下国における国の等級と国庁の関係について検 討する。図 2 に示したように、上国、中国、下国を見ると、大国と 同じく正殿と両脇殿を備え、国庁の建物配置は類似しているが注8)、 最も注目に值するのが国庁の広さである(表 1 )。大国と上国の国庁 の広さには明確な違いが見られないが、これは前述のように軒廊を 用いる特別な形式で上国との差を示し、国庁の広さで差をつける必 要が無かったためである。これに対し、大国以外の国では上国、中 国、下国と移っていくにつれて、国庁は狭くなっている。言い換え ると、大国以外の等級の国では、上国、中国、下国と等級が下がる につれて、国庁の広さは狭くなっていくのである。このことから、 大国を除いた国では国庁の広さが等級に準じて決められていたと推 
定される。

国の等級と国庁の広さには関係が見られるが、例外的に国の等級 とは関係なく、独自の特殊な形式の建物を採用する例も見られる。 伯者国には、楼とみられる注 9$)$ 両脇殿と並んで存在する 4 棟の総柱 建物が存在する。楼は駅家と同様に、官衙を象徵する存在として用 いられていた注 10$) 。 よ り$ 等級の高い大国は、軒廊を用いる形式を採 用したが、上国である伯者国庁は軒廊を用いることができなかった。 そのため、地方支配のために中央権力を誇示する装置として、楼を 用いたのであろう。

この楼とみられる総柱建物は他の国庁には見ることができないこ とから、形式化された大国の正殿と脇殿をつなぐ軒廊とは異なり、 伯者国が独自に採用した形式であると考えられる。

このように各国庁を等級ごとに比較することで、国庁の計画時の ルールについて、以下の 3 点が推定された。

（1）大国のみに正殿と脇殿をつなぐ軒廊が存在する点から、この 軒廊は大国のみに用いられた形式であった。

（2）国庁には建物で囲まれた前庭空間が存在し、特別な形式を用 いた大国以外の国は、等級の高い国から低い国に移るにつれ て、国庁の規模と前庭空間は狭くなる。このことから上国、 中国、下国では国の等級に準じて、国庁の広さが定まってい た。

（３）陸奥、出羽、筑後のように軍事的な要素の強い国庁の前庭空 間は、国の等級に関わらず例外的に広くなる。これには兵土 の集結という機能的な要求が影響しており、建物で囲まれた 前庭空間が重要な役割を担っていた。

\section{3. 郡庁の前庭空間}

これまで述べてきたように、国庁には中心軸上に複数の建物が存 在する例や脇殿が複数存在する例が存在し、建物配置に明確な共通 点があるとは言い難い。

郡庁では正殿が存在しない例や長舎によって政庁域を囲繞するこ とも多く、国庁以上に共通点を見出すことは難しい。

しかし郡庁において、正殿や脇殿といった建物の規模や数は異な るものの、現在までに発掘されている郡衙遺跡（文末発掘調査報告 書一覧参照）の政庁域には、国庁と同様に、前庭空間が必ず存在す る注11)。図 3 はその 4 例である。

郡庁に前庭空間が存在することは、『上野国交替実録帳注 12$) 』 の ~$ 次の記述からも知ることができる。

那波郡 (中略)

郡廳壹宇

向屋壹宇 公文屋壹宇 副屋壹宇

(中略)

新田郡（中略）

郡廳

東 $\square$ 屋壹宇 西長屋壹宇 南長屋壹宇

$\square \square$ 屋壹宇 公文屋壹宇 欴壹宇

(後略)

那波郡には向屋という建物が記述される。この向屋は、2 棟の建 物が互いに向かい合って対をなす建物を指すとみられ、脇殿の一方 であると考えられる。そこから正殿と両脇殿によって囲まれた前庭
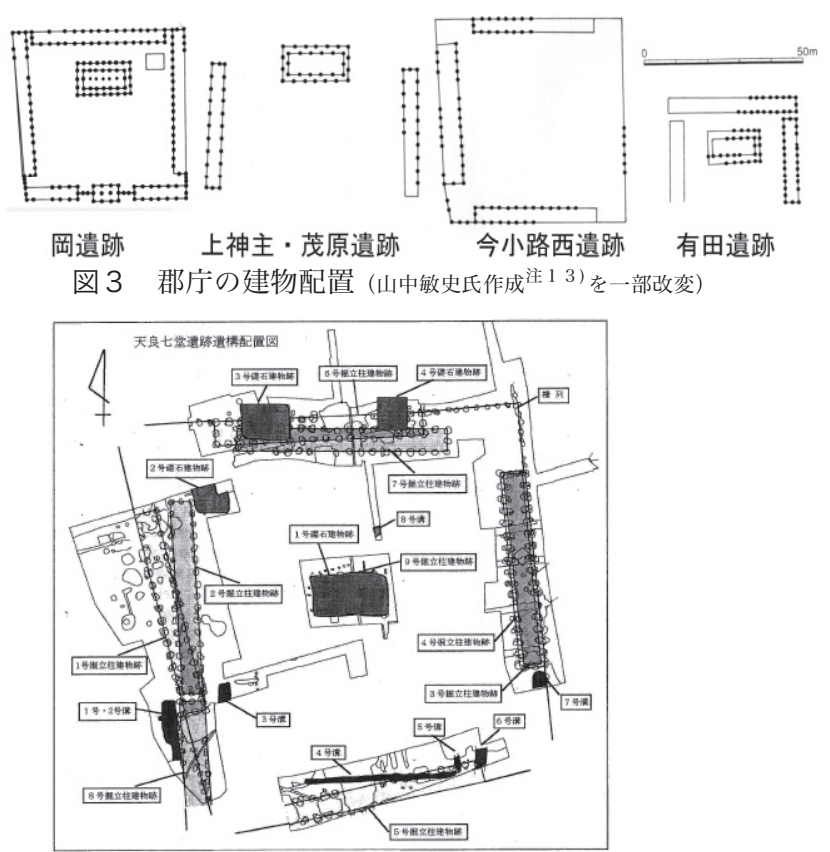

図 4 天良七堂遺跡遺構配置図 (シンポジウム注 14 ) 配付資料)

の存在が読み取れる。

新田郡の記述は郡庁の様子をもっとも良く示しており、東西南北 の四方を長屋によって囲み、前庭空間を構成するという形式をとっ ている。

この新田郡衙と比定される発掘遺構として、2007 年に群馬県太田 市天良町 7 番地内の天良七堂遺跡が発見された。この遺跡では、図 4 のように郡庁域の東西南北の四方に細長い建物が位置し、これら の建物が『上野国交替実録帳』の記述にある長屋と見られている。 この遺跡が発見されたことによって、文献史料と発掘史料の両面か ら、郡庁に前庭空間が確かに存在していたことが明らかになった。

\section{4. 前庭空間における儀式}

現在までに発掘されている地方官衙の発掘史料を検討すると、国 庁、郡庁のすべてに前庭空間は存在する。この前庭空間は地方官衙 に必須の空間であったのではないだろうか。国庁や郡庁の前庭空間 で行われていた儀式について検討する。

まず国庁において国司や郡司が執り行う儀式について検討する。 これには元日拝賀、饗宴、告朔の 3 つが挙げられる。

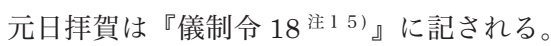

凡元日。国司皆率僚属郡司等。向廳朝拝。訖長官受賀。設宴者

聴。其食以当処官物及正倉死。所須多少従別式。

元日拝賀とは、元日に国庁において執り行う拝賀の儀式である。 これは中央で天皇を「庁」つまり大極殿に据えて、官人が择賀する ことに対応している。国庁では国司が郡司を率いて、「庁」すなわ ち正殿に向かって拝賀し、その後、饗宴を執り行う。元日拝賀が国 庁において実際に執り行われていたことは、現在までに発掘されて いるすべての国庁に前庭空間が存在するという事実が裏付けてい る。

饗宴については、『万葉集 4136 注 1 6)』の大伴家持の歌に、郡司と ともに国庁で行ったことが記されている。

天平勝寶二年正月二日、於國廳給饗諸郡司等宴歌一首。 
安之此奇能 夜麻能許奴礼能 保与等理天 可射之都良久波 知等世保久等曾

右一首、守大伴宿祢家持作

大伴家持は天平 18 年（746）から天平勝宝 3 年（751）の間、越 中国に国守として赴任していた。その任期中である天平勝宝 2 年 （750）に国庁で、郡司とともに饗宴を行いながら作った歌の一首 である。ここに記されるように、国庁において饗宴は執り行われて いたのである。

告朔は各官司が前月の公文を朝堂院において、天皇に奏上する行 政報告の儀式である。地方においても中央と同様に毎月郡司から国 司への告朔帳が提出されていた注 17$)$ 。中央において告朔が朝堂院で 行わ机たように、国における告朔の儀式も国庁で行われたと推定さ れる。

郡庁における儀式について具体的に記述された文献史料は見当た らないが、郡庁は国庁と同様に前庭空間を必ず有しており、郡庁に おいても国庁と同じように前庭空間において儀式が行われていたと 考えられる。よって国庁における儀式をもとに郡庁の前庭空間にお ける儀式を推定する。

国司が郡庁において儀式を行う機会は限られる。その機会の一つ として、国司が郡へ巡行する部内巡行注18) があげられる。この際 に、郡庁において行われた儀式として、国庁と同様に国司を正殿に すえた儀式や饗宴が考えられる。

饗宴については『戸令 34 注19)』によって、国司が巡検する際の 接待を禁じるょう規定された。この規定は、国司に対する接待が禁 止されて行われなかったというよりは、むしろ国司に対する接待が 横行していたために、この接待を禁止したということを暗に示して いる。その際の饗宴は、国において饗宴が国庁で行われたように、 郡においては郡庁において行われたと考元られる。

これらの国司の部内巡行時の儀式以外に、郡の下部組織である郷 の行政報告の際にも、国庁の告朔と同様の儀式が郡庁において行わ れたと考えられる。

このように国庁や郡庁に前庭空間が必ず存在する理由として、そ こで行われる儀式が深く関係していた。この儀式として国庁では、 元日拝賀、饗宴、告朔といった儀式が執り行われていた。そして郡 においては、国司の部内巡行の際に、国司を接待するために饗宴が 行われた。その饗宴は国において国庁で行われたのと同様に、郡で は郡庁で執り行われたと考えられるのである。

\section{5. 前庭空間の祖形}

これまで述べてきたように、現在にまでに発掘されている国庁や 郡庁には全て前庭空間が存在した。前庭空間では儀式が行われてお り、この前庭空間が非常に重要な位置を占めていた。ではこの前庭 空間は律令制度とともに導入された新しい空間であるのだろうか、 それとも律令制度の導入以前から存在する空間であるのだろうか。 この点を明らかにするためには、律令制導入以前の政務空間につい て考える必要がある。

まず宮城の構成に着目し、天皇の私的空間と政務空間が分離して いたか、否かという点について検討する。そのため、ここでは 8 世 紀以降の平城宮や平安宮といった天皇の私的空間である内裏空間と 政務空間である朝堂院や大極殿が分離したものを「分離型」それ以

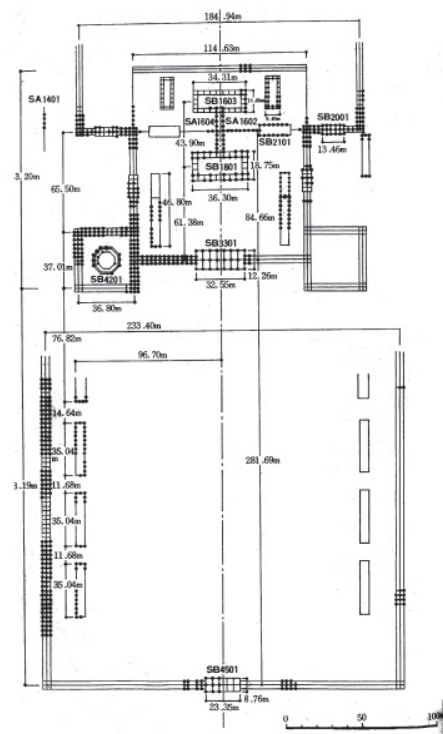

図 5 難波宮内裏

(出典 : 大阪市文化財協会『難波宮址の 研究第七 報告篇』p.154 1981 年)

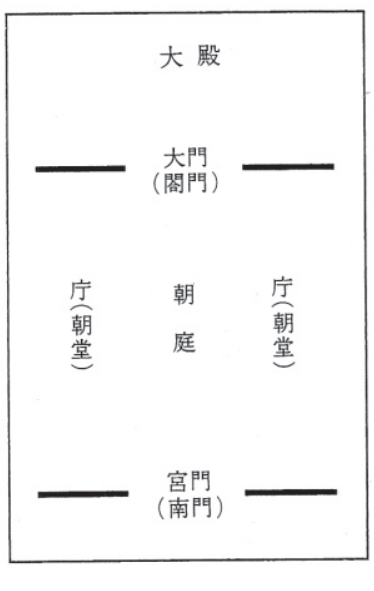

図 6 小墾田宮復原図 (岸俊男氏作成注 20 ) )
前の 7 世紀の宮にみられる未分離のものを「一体型」とする。

山中敏史氏や阿部義平氏は、地方官衙の建物配置の祖形を、8世 紀の律令制下の平城宮といった「分離型」宮城の官衙や朝堂院に求 めてきた。しかし地方官衙の政庁域の建物配置は朝堂院とは脇殿の 数が大きく異なる。

そこで 7 世紀の前期難波宮を対象に、前庭空間について検討を加 える。この前期難波宮の造営年代は明らかになっておらず、孝徳朝 と天武朝の二つの時期注 21 ) が考えられているが、両説とも 7 世紀 中期から後期である。

前期難波宮は図 5 のように内裏前殿区域と後殿区域が未分離で、

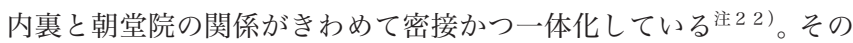
ため、前期難波宮は、律令制の「分離型」宮城ではなく、「一体型」 の宮としてとらえることができる。

前期難波宮の内裏空間（図 5 ）は、内裏前殿と長い脇殿の建物配 置によって構成される。特に内裏前殿及び両脇殿によって、前庭空 間を構成する点は、地方官衙において、正殿と両脇殿によって前庭 空間を構成する点と同じである。

このように 7 世紀に造営された前期難波宮に前庭空間は存在した、 言い換えれば、前庭空間は「分離型」以前の「一体型」の宮に存在 したのである。

前庭空間は 7 世紀の「一体型」の宮である前期難波宮内裏に存在 することが、発掘史料から確認できた。ではこの前庭空間は、前期 難波宮以前に存在したのであろうか。

岸俊男氏は推古朝の小墾田宮（図 6 ）において、当時の宮室は朝 堂・朝庭を備え、朝参、朝政が行われていることから、すでに内裏

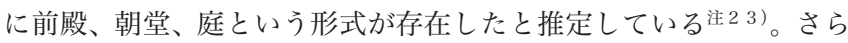
に小墾田宮の初期の宮室からすでに朝堂が存在し、そこでは、執政 はともかくとして、当初は有位者すべてが、毎日早朝から朝参して いることを指摘している注 24$) 。$

このように 7 世紀の段階で、すでに内裏前殿・朝堂・庭主 25) と いう宮の形式が確立し、律令制以前から、官人が朝庭における儀式 
に参加していた。つまり律令制度導入以前の「一体型」の宮に、す でに前庭空間が存在したのである。

では果たして、朝庭空間が律令制にともなった「分離型」の宮城 ではなく、「一体型」の宮と同形式の空間を有すことは、国庁に前 庭空間が存在することとどのような関係があるのだろうか。これは 7 世紀の天皇ないし朝廷の命を奉じて地方に赴任する官人である 「クニノミコトモチ」が、律令制のもとで国司へと変化したことと 関係がある。

もともと国司は、「天皇の代理」として、天皇の「ミコト」すな わち天皇の言葉を持って一時的に地方へ赴任した「クニノミコトモ チ」であった。それが 8 世紀になって地方に常駐する国司へと変化 した注 2 6)。そのため天皇が大殿に出御し、臣下が朝庭に参列するの と同様に、「クニノミコトモチ」である国司が天皇の代理として正 殿、在地の隷属集団である郡司が前庭空間という形式が重視された と考えられる。

その結果、国庁において前庭空間で儀式を行う必要から、前庭空 間を必須のものとして計画したのである。この前庭空間が必要な空 間であったことは、現在までに発掘されている国庁・郡庁の全てに 前庭空間が存在するという事実が示している。

そして宮において天皇と臣下の関係を朝庭空間で表したょうに、 地方において、天皇の代理である「クニノミコトモチ」と郡司とい う関係を、国庁の前庭空間で実現したと考えられる。

このように前庭空間は、天皇の私的空間から政務空間が分離した 朝堂院や太政官院といった、律令制度とともに導入された新しい空 間ではなく、それ以前の天皇の私的空間と政務空間が一体化した宮 にその祖形は存在した。

つまり前庭空間は、律令の儀式を行うために新たに成立したので はなく、律令制度導入以前から存在し、地方官衙の政庁域は、この 前庭空間を中心に構成されたのである。

\section{6. まとめ}

以上、発掘史料と『上野国交替実録帳』や『律令』を中心に、地 方官衙の政庁域の構成について考察した。そして以下の 6 点が推定 された。

（1）地方官衙において、前庭空間は儀式空間として重要な役割を果 たした。そして筑後、多賀城、出羽などの対外的緊張感の高い 辺境の国では、軍団兵士の集結のために広い前庭空間が必要で あった。

（2）国の等級ごとに国庁を比較すると、大国には上国、中国、下国 には見られない軒廊という形式が存在した。

（3）上国、中国、下国は国の等級が下がるにつれて、国庁や前庭空 間が狭くなることから、国の等級に準じて、国庁の広さが定め られていたと推定された。ただし、軍事的に重要な国の国庁は、 前述のように例外的に広い前庭空間が設けられた。

(4) 国庁や郡庁の建物自体の数や規模には共通点は見出しがたい が、これまでに発掘された国庁、郡庁のすべてにおいて前庭空 間が存在した。

（5）この前庭空間が重要な役割を果たしており、そこでは地方官人 が参加する儀式が行われていた。国では、元日洋賀、饗宴、告 朔などの儀式が国庁において執り行われていた。郡では、国司
が部内を巡行する際の接待として饗宴が行われ、その饗宴は郡 庁で執り行われたと推定された。

（6）これまで、地方官衙は律令制度によって作られた新しい施設で あると指摘されていたが、前庭空間に着目することで、それが 律令制度以前から存在する宮の形式を受け継いでいたと判明 した。そして天皇と臣下という空間構成を宮の朝廷空間で表現 したように、地方官衙においても、天皇の代理である「クニノ ミコトモチ」と地方豪族である郡司という関係を国庁の前庭空 間において再現し、律令制支配を強めようとする意図が見られ た。

注

注 1 ）山中敏史『古代地方官衙遺跡の研究』塙書房 1994 年

なお、史料上の用語としては『上野国交替害録帳』に記載される。『上 野国交替実録帳』は長元 3 年 $(1030)$ に上野国司の交替に際して作成され た文書の草案で、九条家本延喜式の巻第 16、20、32、38 の紙背文書であ る。『平安遺文』第 9 巻 (4609 号) 及びそれを元に再校訂した『群馬県史』 資料編 4 (群馬県史編さん委員会編 1985 年）に収録されているものを用い る。「佐位郡八面甲倉」と比定される建物として、三軒屋遺跡から八角形 の総柱建物が発掘されたことから、上野國交替実録帳の史料としての信頼 度は高く評価されている。

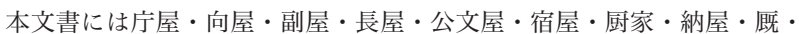
舘屋の建物名が用いられる。郡庁においては建物ごとの機能が明らかとな つていないことから、史料上の用語ではなく、正殿・前殿・後殿・脇殿の ように配置が明確となる山中敏史氏の用語に倣う。

注 2) 郡庁に多くみられるように、築地塀や柵などによる建物から独立した 囲繞施設が存在せず、建物によって政庁域を囲む場合は、脇殿ではなく長 屋という語を用いる。

注 3 ）阿部義平「国庁の類型について」『国立歴史民俗博物館研究報告』10 1986 年

注 4 ）山中敏史『古代の官衙遺跡 II 遺物・遺構編』独立行政法人文化財研究 所奈良文化財研究所 2003 年 p.134

なお、この文献は地方官衙研究の基礎資料集である。

注 5 ) 同上 p. 133 を一部改変

注 6 ）『民部式』によると、大国は、大和、河内、伊勢、武蔵、上総、下総、 常陸、近江、上野、陸奥、越前、播磨、肥後の 13 国である。上国は、山城、 摂津、尾張、三河、遠江、駿河、甲斐、相模、美濃、信濃、下野、出羽、 加賀、越中、越後、丹波、但馬、因幡、伯者、出雲、美作、備前、備中、 備後、安芸、周防、紀伊、阿波、讃岐、伊予、筑前、筑後、豊前、豊後、 肥前の 35 国である。中国は、安房、若狭、能登、佐渡、丹後、石見、長門、 土佐、日向、大隅、薩摩の 11 国である。下国は和泉、伊賀、志摩、伊豆、 飛騨、隠岐、淡路、壱岐、対馬の 9 国である。

注 7 ) 『職員令』によると、大国は守 1 人、介 1 人、大掾 1 人、少橡 1 人、 大目 1 人、少目 1 人、史生 3 人の計 9 人に対し、上国は守 1 人、介 1 人、 橡 1 人、目 1 人、史生 3 人の計 7 人が任じられている。

史生は公文書を繕い写し、文案を整理・作成し、四等官の署名を得るこ とを担当している下級書記官である。この下級書記官である史生の人数が 同じであることから、業務量もほぼ同じであると推定できる。

注 8 ） 日向国庁や伊賀国庁の脇殿の北側に、正方形プランの建物が存在する が、これがぞのような機能を持つ建物であるかは不明である。しかし、桁 行の長い脇殿とは平面が異なる。

注 9 ) 伯者国には 4 棟の総柱の建物が見られる。総柱建物は構造耐力が大き く、この点から考えるとこの総柱建物は正倉、公文屋、楼の 3 つの可能性 が考えられる。正倉や公文屋は、収容される内容物の重量、楼は二層以上 であるため、建築物自体が重いと考光られるためである。

正倉は『倉庫令 1 』倉は官舎から 50 丈離すことを定められており、政 庁域に正倉が存在したとは考えにくい。さらに正倉は建築群を形成し、正 倉院の形をとることが多く、正倉ではないと考元られる。

公文屋は国庁の機能上、どの国においても必要であったにもかかわらず、 大国の政庁域に同様の総柱建物は存在しない。国庁域に公文屋を抢く必要 があるのであれば、他の国庁にも伯者国と同様に総柱建物が存在するはず である。このことから伯者国のみに存在する総柱建物が公文屋である可能 性は低い。 
注 10 ）『扶桑集』巻 7 菅丞相の詩に「駅楼執手泣相分」と記され、『菅家 文草』巻 4 に「題駅楼壁」という詩があり、駅楼の存在が窥える。駅家は 『日本後紀』大同元年 5 月 14 日条に「本備蕃客、瓦草粉壁」とある。蕃客 に備えるために瓦惪、白壁とすることを求めており、官衙の威厳を示す施 設であった。

注 11 1) 現在までに政庁域が判明した郡衙と比定される遺跡は、文末の発掘 調査報告書一覧及び天良七堂遺跡である。

注 1 2) 注 I) 参照。

文書の内容は、国司の交替の引継ざのために建物を含めた品目ごとに名 称・員数・法量を揭げて前回の交替時の検査と現況の比較するものである。 項目ごとに、先ず破損の状況およびその理由を揭げ、既に無くなってし まい無実となっていたものについては「前日記」（前回に作成された記録） を引用することによって示し、それを現状と比較する形式をとる。前回と 異同がない場合には「今検同前」と記されている（前田和之『群馬県史 4 』 資料編 4 p.1259）。そのためすべての建物の名前が記されているわけで はない。

注 13 ）＼cjkstart注 4） 前揭書 p.161

注 $14 ） 2008$ 年度国史学会大会古代史シンポジウム「北関東の郡家と地域 社会」（國學院大学 2008 年 5 月 25 日）

注 15 ） 『律令』日本思想大系新装版 岩波書店 1994 年

注 16 ) 『万葉集 4』日本古典文学大系 岩波書店 1962 年

注 17 ）『儀制令 5』注 15 ）前掲書

『国史大辞典』告朔（こうさく）の項によると、中央においては、毎月一 日、朝堂院において、各官司の前月の公文を天皇に奏上する行政豊国の儀 式。地方において、毎月郡司から国司へ告朔帳が提出されており、毎月の 行政報告も告朔と呼ばれていた。

注 18 ）『戸令 33 』注 15 ）前掲書。国守が年に 1 度、属郡を巡行し、風 俗を観て、古老に古事等を問い聞き、贝徒について記録し、裁判の不正を 正し、政ごとや刑罰の得失を詳しく視察し、百姓の憂い苦しむところを知 り、五教を諭し、農の功を勧め務めさせること。

注 19 ） 注 15 ）前揭書

注 20 ）岸俊男『日本の古代宮都』岩波書店 1993 年 p.19

注 21 ） 中尾芳治『難波宮の研究』吉川弘文館 1995 年 p.108

孝徳朝説は、難波宮跡の発掘担当者を中心として出された考えである。 朱鳥元年に消失した遺構をそのままのかたちで孝徳朝まで遡らせ、前期難 波宮跡を難波長柄豊碕宮とする。

これに対し天武朝説は、長柄豊倚宮の完成した白雉 3 年（652）12 月か ら消失した朱鳥元年 (686) 正月まで 33 年を経過していることを指摘する。 少なくとも一度の造替痕跡があってしかるべきであるにもかかわらず、一 部をのぞいて前面に造替痕跡がないことと、前期の遺構に示される大規模 かつ朝堂院を伴う整然とした殿舎配置が孝徳朝よりは天武朝の国制により ふさわしい点の 2 点から、前期難波宮は天武朝の造営と考える説である。

注 22 ） 中尾芳治氏も同様の見解を示している（同上p.106）。

注 23 ) 注 20 ) 前揭書 p.22

注 24 ）岸俊男『日本古代宮都の研究』岩波書店 1988 年 p.256

なお小澤毅氏は小鲑田宮と鴆宮で機能を分掌し、両宮が有機的に結合し 単体の宮ではなく、総体として宮都空間が成立し当初より一定の計画のも とに配置されたものではなく、本格的な都城の成立に向けての過渡的状況 であるとしている（小澤毅『日本古代宮都構造の研究』青木書店 2003 年 pp.102-103)。

注2 5 ) 林部均「飛鳥浄御原宮の庭と朝庭・朝堂」『古代宮都形成過程の研 究』青木書店 2001 年

林部均氏は、伝承板蓋宮跡と飛鳥浄御原宮には、「庭」「朝庭」「朝堂」 の三つが存在したことを指摘している。そして庭空間は、小啯田宮におい ても見られ、首長居館以来の飛鳥の宮がもつ伝統的な要素であったとする。 注 26 ）『国史大辞典』国峷（くにのみこともち）の項によると、天皇ない し朝廷の命を奉じて地方に赴任する官人の総称で、臨時に地方に赴く官人 のこと。

また『国史大辞典』国司（こくし）の項よると大化前代の地方官という べきは国造・県主であり、また時に天皇あるいは朝廷の命を奉じて地方に 赴く臨時の官としての「みこともち」（国宰）があったが、後の国司のよ うに一定期間、現地に常駐して任務を遂行する地方官は存在しなかった。

\section{発掘調査報告書一覧}

国庁

陸奥 (多賀城)：宮城県多賀城跡調查研究所『多賀城跡政庁跡本文編』1982
年 近江 : 滋賀県教育委員会『滋賀県文化財調査報告書 第 6 冊』1977 年 伊勢：鈴鹿市教育委員会『伊勢国分寺・国府跡一長者屋敷遺跡ほか発掘調査 事業概要報告一』1994 年、鈴鹿市教育委員会『伊勢国分寺・国府跡 $2 』 1995$ 年 美濃：垂井町教育委員会『美濃国府跡発掘調査報告 II』1999 年 三河： 豊川市教育委員会『三河国府䟢確認調査報告書』 2003 年 下野 : 栃木県教育 委員会『栃木県埋蔵文化財調査報告集第 35 集 下野国府跡 II 一昭和 54 年発 掘調查概報一』1980 年 出羽（秋田城）：秋田市教育委員会『秋田城椢一政 庁跡一』2002 年 出羽（城輪柵）：酒田市教育委員会『史跡城輪柵昭和 59 年度遺構調查概報』1985 年 伯耆: 倉吉市教育委員会『伯老国庁跡発掘調査 概報（第 $5 \cdot 6$ 次）』1979 年 筑後朝妻 : 久留米市教育委員会『筑後国府一 平成 $12 \cdot 13$ 年度発掘調查概要報告- 久留米市文化財調查報告書第 182 集』 2002 年、久留米市教育委員会『筑後国府一平成 15 年度発掘調査報告・概要 報告一 久留米市文化財調査報告書第 200 集』 2004 年 肥前 : 佐賀県教育委 員会『佐賀県文化財調査報告集第 78 集 肥前国府跡 $I I I 1985$ 年 日向：宮 崎県教育委員会『国衙跡保存整備基礎調査報告書』 2001 年 伊賀 : 三重県埋 蔵文化財センター『三重県埋蔵文化財調査報告 99-4 伊賀国府跡（第 4 次） 発掘調查報告』1992 年

郡庁

名生館官衙遺跡: 宮城県多賀城跡調查研究所『多賀城関連遺跡発掘調査報告 書第 6 冊 名生館遺跡 I 』1981 年、古川市教育委員会『宮城県古川市文化財 調査報告書第 8 集 名生館官衙遺跡IX』1989 年、古川市教育委員会『宮城県 古川市文化財調查報告書第 9 集 名生館官衙遺跡X』1990 年 東山官衙遺 跡: 宮城県多賀城跡調查研究所『多賀城関連遺跡発掘調査報告書第 18 冊 東 山遺跡VII 1993 年 三十三間堂遺跡: 宮城県教育委員会『宮城県文化財報告 書第 131 集 亘理町三十三間堂遺跡ほか』1989 年 神野向遺跡: 茨城県鹿島 町教育委員会『鹿島町の文化財第 46 集 神野向遺跡 $\mathrm{V}$-昭和 59 年度発掘調 査概報一』1985 年 上神主・茂原遺跡：上三川町教育委員会・宇都宮市教育 委員会『上神主・茂原官衙遺跡』2003 年 嶋戸東遺跡: 千葉県教育委員会『成 東町嶋戸東遺跡発掘調査報告書』1998 年、千葉県教育委員会『成東町嶋戸東 遺跡第 3 次発掘調査報告書』 2000 年、千葉県教育委員会『成東町・山武町嶋 戸東遺跡第 4 次発掘調查報告書』 2001 年、千葉県教育委員会『千葉県山武郡 成東町 ・ 山武町嶋戸東遺跡第 $6 \cdot 7 \cdot 8$ 次発掘調査報告書』 2006 年 御殿前遺 跡: 東京都北区教育委員会社会教育課『北区埋蔵文化財調査報告第 4 集 御 殿前遺跡』1988 年 今小路西遺跡: 今小路西遺跡発掘調査団『神奈川県鎌倉 市 今小路遺跡（御成小学校内）発掘調查報告書第 1 分冊本文篇』 1990 年、 今小路西遺跡発掘調査団『神奈川県鎌倉市 今小路遺跡（御成小学校内）発 掘調查報告書第 2 分冊図版篇』 1990 年 下寺尾西方 $\mathrm{A}$ 遺跡: 財団法人かなが わ考古学財団『かながわ考古学財団調查報告 157 下寺尾西方 $\mathrm{A}$ 遺跡』2003 年 弥勒寺東遺跡 : 関市教育委員会『美濃国武義郡衙 弥勒寺東遺跡一第 1 5 次発掘調查概要一』1999 年 岡遺跡: 栗東町教育委員会『岡遺跡発掘調査 報告書 1 次・ 2 次・ 3 次調査』 1990 年 正道官衙遺跡: 城陽市教育委員会『正 道官衙遺跡 (城陽市埋蔵文化財調査報告書第 24 集)』1993 年 万代寺遺跡: 郡家町教育委員会『万代寺遺跡発掘調査報告書』1983 年 古志本郷遺跡：島 根県教育委員会『古志本郷遺跡 V 出雲国神門郡家関連遺跡の調査 斐伊川 放水路建設予定地内埋蔵文化財発掘調査報告書XVI』2003 年 下本谷遺跡： 下本谷遺跡発掘調査団『下本谷遗跡—推定備後国三次郡衙跡の発掘調査報告 -』1975 年、広島県埋蔵文化財センター『下本谷遺跡第 6 次発掘調査概報』 1985 年 小郡官衙遺跡: 小郡市教育委員会『小郡遺跡 小郡市文化財調查報 告書第 6 集』1980 年 有田遺跡：福岡市教育委員会『有田・小田部 33 福 岡市埋蔵文化財調査報告書第 649 集』 2000 年 大八瀬官衙遺跡: 新吉富村教 育委員会『大/瀬下大坪遺跡 新吉富村文化財調查報告書第 10 集』 1997 年

(2009年 5 月 7 日原稿受理, 2009 年 8 月 10 日採用決定) 